\title{
Flora do Espírito Santo: Hymenophyllum (Hymenophyllaceae)
}

\author{
Flora of Espírito Santo: Hymenophyllum (Hymenophyllaceae)
}

\author{
Felipe Gonzatti ${ }^{1,2,3} \&$ Paulo Günter Windisch ${ }^{2}$
}

\begin{abstract}
Resumo
É apresentado o inventário das espécies do gênero Hymenophyllum (Hymenophyllaceae) ocorrentes no estado do Espírito Santo. O tratamento taxonômico inclui descrições das espécies, comentários e imagens dos táxons, bem como, chaves de identificação dos gêneros de Hymenophyllaceae ocorrentes na área de estudo e no Brasil e das espécies de Hymenophyllum ocorrentes no Espírito Santo. O padrão de distribuição das espécies, juntamente com observações ecológicas também estão inclusos. No total foram encontradas 15 espécies pertencentes a cinco subgêneros. As espécies ocorrem amplamente no bioma Mata Atlântica, em florestas ombrófilas e nebulares, com exceção de Hymenphyllum caparaoense que é endêmica no Parque Nacional do Caparaó.

Palavras-chave: biodiversidade, filicíneas, florística, Mata Atlântica, samambaias.
\end{abstract}

\begin{abstract}
The inventory of species of Hymenophyllum (Hymenophyllaceae) occurring in state of Espírito Santo is presented. The taxonomic treatment includes description, comments, images and key of species of Hymenophyllum occurring in state of Espírito Santo, as well as, a key for Hymenophyllaceae genera occurring in study area and Brazil. The geographical distribution pattern and ecological notes also are included. A total of 15 species belonged to five subgenera were recorded. The species are wide distribution in Atlantic Forest biome, in ombrophiles forest and nebular forest, with exception of Hymenophyllum caparaoense which is endemic of Caparaó National Park.
\end{abstract}

Key words: biodiversity, filices, floristic, Atlantic Forest, ferns.

\section{Introdução}

Hymenophyllaceae Mart. compreende cerca de 600 espécies distribuídas nas florestas tropicais úmidas com poucos representantes nas regiões temperadas (Iwatsuki 1990). Sua distribuição está relacionada predominantemente aos ambientes florestais, nebulares, entornos de cachoeiras e sobre rochas úmidas ao longo de riachos (Ebihara et al. 2007). Sua morfologia é distinta dentre as samambaias, pois a maioria das espécies apresenta uma única camada de células de espessura no tecido laminar (Iwatsuki 1990). Esta característica, juntamente com soros marginais em forma de indúsio tubular-campanulado ou bivalvo e com esporângios apresentando ânulo oblíquo em relação ao receptáculo, constituem sinapomorfias importantes para a delimitação de
Hymenophyllaceae como um grupo monofilético (Tryon \& Stolze 1989; Pryer et al. 2001; Smith et al. 2006; Ebihara et al. 2006; Christenhusz \& Chase 2014).

Segundo a classificação proposta por Ebihara et al. (2006) são aceitos nove gêneros, sendo as espécies com indúsios bivalvos inclusas em um único gênero (Hymenophyllum) e as demais, com indúsios tubulares, foram segregadas em oito gêneros distintos: Didymoglossum Desv., Crepidomanes C.Presl, Polyphlebium Copel., Vandenboschia Copel., Trichomanes L., Abrodictyum C.Presl, Cephalomanes C.Presl e Callistopteris Copel.

O gênero Hymenophyllum compreende cerca de 250 espécies distribuídas em todo o mundo (Ebihara et al. 2006). Recentemente os estudos filogenéticos com o gênero, utilizando os

\footnotetext{
${ }^{1}$ Universidade de Caxias do Sul, Herbário, R. Francisco Getúlio Vargas 1130, 95070-560, Caxias do Sul, RS, Brasil.

${ }^{2}$ Universidade Federal do Rio Grande do Sul, Depto. Botânica, Prog. Pós-graduação em Botânica, Campus do Vale Prédio 43433, 91501-970, Porto Alegre, RS, Brasil.

${ }^{3}$ Autor para correspondência: fgonzatti@ucs.br
} 
marcadores $r b c L$, rps4-trnS e rps4, têm revelado a história evolutiva deste grupo (Pryer et al. 2001; Hennequin 2003; Hennequin et al. 2010). Ebihara et al. (2006) propuseram uma divisão do gênero em 10 subgêneros, com base em análises filogenéticas e morfológicas, sendo: Cardiomanes (monotípico da Nova Zelândia), Diploöphyllum (monotípico da Nova Zelândia), Fuciformia (duas espécies distribuídas no sul do Chile e Nova Zelândia), Pleuromanes (cerca de cinco espécies distribuídas no Paleotrópico, especialmente na região do Pacífico).

No Brasil, ocorrem os subgêneros Hymenophyllum (cerca de 100 espécies de distribuição cosmopolita), Mecodium (cerca de 35 espécies e distribuição cosmopolita), Globosa (cerca de 25 espécies, distribuição na Ásia e Pacífico com apenas uma espécie na América), Hymenoglossum (três espécies conhecidas, ocorrendo no centro e sul da América e Madagascar), Myrmecostylum (oito espécies conhecidas, distribuídas no sul da América, Nova Zelândia e Nova Caledônia) e Sphaerocionium (cerca de 70 espécies de distribuição cosmopolita mas com maior diversidade no Neotrópico) (Ebihara et al. 2006).

Atualmente estima-se que, no Brasil, a família Hymenophyllaceae esteja representada por cerca de 88 espécies e o gênero Hymenophyllum por 32 espécies, distribuídas em todas as formações florestais, sendo a Amazônica e a Mata Atlântica, os biomas mais diversificados, e em ambos os biomas, carecem de revisões taxonômicas ou estudos florísticos com o grupo (Prado et al. 2015).

A Mata Atlântica constitui um dos biomas mais importantes para a ocorrência de samambaias e licófitas no Brasil, apresentando alta riqueza florística e elevadas taxas de endemismos (Salino \& Almeida 2008). Neste contexto, o estado do Espírito Santo compreende uma das áreas com maior riqueza de espécies de samambaias e licófitas (439) (Prado et al. 2015), devido a apresentar uma diversidade fitofisionômicas que inclui Formações Pioneiras, Florestas Estacionais e Florestas Ombrófilas (Garbin et al. 2017), mas ainda pouco conhecido pela escassez de inventários florísticos e floras detalhadas.

O histórico acerca dos estudos taxonômicos e de inventários florísticos no estado do Espírito Santo não é extenso, visto que são poucos os trabalhos que surgem na bibliografia, dentre eles estão: Brade (1947), Behar \& Viégas (1992),
Viégas-Aquije \& Santos (2007), Andrade et al. (2016), Sylvestre et al. (2016), nos quais a família Hymenophyllaceae aparece com poucos representantes (de 2 a 11 espécies são apontadas nos levantamentos acima citados). Tal fator pode estar atrelado a carência de amostragem, mas também pela falta de chaves de identificação para correta determinação das espécies.

O objetivo desse trabalho é apresentar a primeira parte do tratamento taxonômico das espécies de Hymenophyllaceae ocorrentes no estado do Espírito Santo, que corresponde ao gênero Hymenophyllum, fornecendo ilustrações, descrições das espécies e comentários acerca da taxonomia, distribuição geográfica e habitat de cada uma.

\section{Material e Métodos}

Para a compilação desta listagem, foram realizadas revisões nos materiais dos seguintes herbários: BHCB, CESJ, HUCS, ICN, MBML, SP, SPF, UPCB e VIES (acrônimos conforme Thiers, continuamente atualizado). Os materiais depositados no Herbários NY e RB foram consultados de forma virtual, por meio das imagens disponibilizadas. As definições nomenclaturais de morfologia seguiram Lellinger (2002), com exceção dos tricomas, no qual foi adotada a nomenclatura descrita por Morton (1947). A delimitação das espécies foi baseada nos conceitos aplicados nas mais diferentes revisões taxonômicas do grupo, bem como de floras realizadas no Neotrópico, sendo: Morton (1947), Diem \& Lichtenstein (1959), Stolze (1976), Kramer (1978), Proctor (1985), Lellinger (1984), Lellinger (1989), Tryon \& Stolze (1989), Windisch (1992; 2014), Larsen et al. (2013), bem como no conhecimento dos autores.

Observações de hábitat e ecologia foram obtidos com base na bibliografia, informações presentes nas exsicatas e observações diretas em campo. As definições de altitude referem-se à variação altitudinal da espécie dentro de seu padrão geral de distribuição, conforme observado no material examinado e na bibliografia. Algumas espécies, mesmo sem registros explícitos dentro da área política do estado do Espírito Santo foram inclusas por apresentarem ocorrência em áreas limítrofes. As imagens detalhadas dos esporófitos foram obtidas de espécimes representativos depositados nas coleções supracitadas, através de estereomicroscópio Leica EZ4D com câmera acoplada. 


\section{Resultados e Discussão}

Hymenophyllaceae Mart., Consp. Regn. Veg. 3. 1835.

Plantas geralmente terrestres, rupícolas, epífitas ou hemiepífitas, ocorrendo em ambientes úmidos, juntos a cursos d'água; caule geralmente fino, rizomatoso, longo, coberto por tricomas, por vezes robusto e ereto dando origem a plantas rosetadas; frondes normalmente monomorfas, espaçadas ou fasciculadas, dimorfas em algumas espécies, sem articulação com o rizoma, inteiras, flabeladas ou lineares até mais de três vezes decomposta; escamas ausentes, porém com indumento de tricomas muito variados, desde tricomas glandulares unicelulares, simples, ou até 2-3 estrelado pluricelulares; nervação flabelada, catádroma ou anádroma, em geral livre, raramente anastomosante, falsas vênulas presentes ou ausentes; tecido laminar em geral com uma única camada de células; indúsios dos soros marginais, tubulares ou bivalvos, imersos ou não no tecido laminar, às vezes pedunculados; receptáculo dos soros pode ser curto ou longo, imerso ou exserto ao tubo do indúsio, sempre como um prolongamento da nervura; esporângios sésseis a subsésseis, com anel transversal oblíquo não interrompido pelo pedicelo; esporos triletes e clorofilados de tamanhos variados entre 20 a $100 \mu$.

\section{Chave de identificação dos gêneros de Hymenophyllaceae ocorrentes no estado do Espírito Santo e no Brasil}

1. Indúsio bivalvo, valvas orbiculares, fendidas até a metade ou base do indúsio, nunca tubular; receptáculos geralmente inclusos. Hymenophyllum

1'. Indúsio tubular, obcônico ou infundibuliforme, valvas quando fendidas, somente na porção exserta ao tubo; receptáculo filiforme, geralmente exserto.

2. Plantas com poucas raízes sobre o rizoma, estas delicadas $(0,2-0,4 \mathrm{~mm}$ diam.), ou ausentes.

3. Frondes geralmente pequenas, menos de $5 \mathrm{~cm}$ comp., inteiras, flabeliformes ou pinatífidas; falsas vênulas presentes no tecido laminar; raízes verdadeiras ausentes ...... Didymoglossum

3'. Frondes em geral maiores que $6 \mathrm{~cm}$ comp., fronde mais decomposta, raro inteira, falsas vênulas ausentes no tecido laminar, raízes verdadeiras presentes ou ausentes.

4. Raízes verdadeiras presentes, finas; indúsios tubulosos ou infundibuliforme; alas da raque plana ou levemente ondulada Polyphlebium

4'. Raízes verdadeiras ausentes; indúsios obcônicos; alas da raque ondulada. Crepidomanes

2'. Plantas com numerosas raízes, robustas $(0,5 \mathrm{~mm}$ ou mais diam.).

5. Tricomas ausentes nas margens dos segmentos laminares.

6. Caule reptante; frondes espaçadas, tricomas clavados presentes no estípite e raques.... Vandenboschia

6'. Caule ereto a subereto; frondes cespitosas, tricomas clavados ausentes no estípite e raque Abrodictyum

5'. Tricomas presentes nas margens dos segmentos laminares Trichomanes

Hymenophyllum J. E. Smith, Mém. Acad. Roy. Sci. Turin 5: 418, t.9, fig. 8. 1793.

Plantas epífitas, rupícolas, humícolas ou ocasionalmente terrestres. Caule rizomatoso, longo reptante, filiforme, ou raro robusto, geralmente provido de tricomas castanhos a avermelhados adpressos ou patentes; frondes geralmente espaçadas, determinadas ou não. Frondes férteis e estéreis isomorfas, simples, pinatissectas muitas vezes decompostas, 2-60 cm compr.; estípite delicado a rígido, frequentemente alado, principalmente no subgênero Sphaerocionium recoberto por distintas combinações de tricomas; lâmina desde lineares a deltoides, nervação anádroma, sem falsas vênulas; segmentos terminais geralmente estreitos e filiformes, com os ápices arredondados ou emarginados, margens inteiras a serreadas; indúsio parcialmente ou não imerso no tecido laminar, suborbicular a elíptico ou obovado, profundamente fendido ou não, base por vezes cônica, porém nunca tubular; receptáculo filiforme, capitados ou espatulados, curto ou longo, geralmente incluso no indúsio; esporângios 
crescendo ao longo dos receptáculos, ou então somente no ápice desde, em número variado.

Gênero com cerca de 250 espécies, com distribuição majoritariamente tropical, com espécies em áreas temperadas (Ebiahara et al. 2006). No Espírito Santo ocorrem 15 espécies que podem ser distinguidas com base nos caracteres apresentados na chave abaixo.

\section{Chave de identificação das espécies de Hymenophyllum ocorrentes no estado do Espírito Santo}

1. Plantas com tricomas simples ou ramificados, multicelulares, dispersos sobre estípite, raque, nervuras e/ou superfície laminar (Subg. Sphaerocionium).

2. Tricomas presentes no estípite, raque, nervuras e superfície laminar (grupo Lanata).

3. Plantas robustas, lâmina geralmente com mais de 2,5-3,5 cm larg., raque não alada em toda sua extensão, geralmente no último terço distal; tricomas da raque e nervuras densos e de coloração arruivada.

4. Pinas perfeitamente pecioladas; segmentos da pina geralmente simples, poucos bífidos; nervuras com expansões laminares em ambas as faces

10. Hymenophyllum plumosum

4'. Pinas adnatas à raque ao menos a partir do segundo terço distal da fronde; segmentos da pina flabelados, ou mais decompostos; nervuras sem expansões laminares em ambas as faces da pina.

13. Hymenophyllum rufum

3'. Plantas geralmente de dimensões menores (lâmina com menos de $2,5 \mathrm{~cm}$ larg.), raque alada em toda sua extensão; tricomas da raque e nervuras dispersos, e de coloração hialina.

5. Tricomas da superfície laminar e das nervuras estipitados, de comprimento uniforme, com célula basal de $0,1 \mathrm{~mm}$ de compr. ou maiores; pinas formadas por segmentos lineares, simples ou no máximo bífidos nos basais 15. Hymenophyllum venustum

5'. Tricomas da superfície laminar e das nervuras sésseis a subsésseis, de comprimento desigual, geralmente com célula basal menor que $0,1 \mathrm{~mm}$ de comp., apenas alguns tricomas das nervuras atingindo ou ultrapassando esta medida; pinas formadas por 1-5 segmentos flabeliformes. 5. Hymenophyllum fragile

2'. Tricomas restritos ao estípite, raque, nervuras, ou margem da superfície laminar, nunca disperso sobre a superfície laminar (grupo Ciliata).

6. Raque completamente alada em toda sua extensão.

7. Estípite alado em toda sua extensão; tricomas simples, furcados ou estrelados, sobre as nervuras e margem da superfície laminar em ambas as faces da fronde.

6. Hymenophyllum hirsutum

7'. Estípite alado somente no terço distal; tricomas simples, furcados ou estrelados restritos à face adaxial da fronde, face abaxial glabra 8. Hymenophyllum microcarpum

6'. Raque não alada, ou somente alada no terço distal.

8. Lâminas com até 1,5-2,2 cm de larg.; pinas com até 1,5 cm de compr., flabeliformes.. 4. Hymenophyllum elegans

8'. Lâminas com largura superior a $2,5 \mathrm{~cm}$; pinas com mais de $1,5 \mathrm{~cm}$ de compr., romboides ou lanceoladas.

9. Segmentos da pina, em ambos os lados acroscópico e basiscópico, simples, raro primeiro ou segundo par de segmentos furcados ou flabelados na região proximal, junto a raque; tricomas sobre margem da superfície laminar e nervuras estrelados, densos 12. Hymenophyllum pulchellum

9'. Segmentos da pina, em ambos os lados acroscópico e basiscópico, furcados, flabelados ou pinados, somente os últimos segmentos apicais simples; tricomas sobre margem da superfície laminar e nervuras furcados ou furcado-estrelados, esparsos 2. Hymenophyllum caparaoense

1'. Plantas glabras, ou com tricomas com 1-2 células, glandulares ou não, porém nunca estrelados, restritos a raque ou nervuras, perceptíveis somente em frondes jovens. 
10. Margem dos indúsios denteada ou ciliada.

11. Soros dispostos em ambos os lados (basiscópico e acroscópico) da pina; margem dos indúsios ciliada (subg. Myrmecostylum) . 7. Hymenophyllum magellanicum

11'. Soros dispostos somente no lado acroscópico da pina; margem dos indúsios denteada, porém, nunca ciliada (subg. Hymenophyllum) 14. Hymenophyllum tunbrigense

10'. Margem dos indúsios inteira, por vezes ondulada a crispada, porém nunca com recorte evidente.

12. Receptáculos dos soros curto e espatulado, com largura na porção apical superior a $0,3 \mathrm{~mm}$ (subg. Globosa). 3. Hymenophyllum caudiculatum

12'. Receptáculos dos soros longos ou curtos, porém sempre de formato filiforme a clavado, largura nunca superior a $0,3 \mathrm{~mm}$.

13. Frondes inteiras ou pinatífidas (subg. Hymenoglossum).......1. Hymenophyllum asplenioides 13'. Frondes pinadas a 3-4 vezes mais divididas (subg. Mecodium).

14. Indúsios globosos, nunca alongados, ovados ou oblongos; segmentos laminares férteis com uma constrição na superfície laminar junto a base do indúsio; tricomas glandulares de 1-2 células presentes sobre as nervuras em ambas as faces da fronde, mais perceptíveis logo abaixo dos indúsios ..... 9. Hymenophyllum myriocarpum

14'. Indúsios oblongos, ovados ou triangulares; segmentos férteis contínuos, não constritos; nervuras glabras 11. Hymenophyllum polyanthos

1. Hymenophyllum asplenioides (Sw.) Sw., J. Bot. (Schrader) 2: 98. $1800 . \quad$ Fig. 1a

Rizoma filiforme, ramificado, marrom claro, 0,4-5,5 mm diam., tricomas pardacentos, simples, multicelular (5-7 cel.), 1-2 mm compr., adpressos sobre o rizoma, densos junto aos meristemas, escassos e decíduos na maturidade; frondes remotas a contiguas, $(12,5-) 3-15 \times(2,2-) 1,1-3,2 \mathrm{~cm}$, determinadas; estípite marrom, cilíndrico, $0,4 \mathrm{~mm}$ de diam., 1-5,4 cm compr., não alado, ou somente 2-3 mm alado no ápice; lâmina linear, oblonga, ou lanceolada, inteira ou por vezes pinatífida ou pinatissecta, $(8,7-) 2-10,5 \times(2,2-) 1,1-3,2 \mathrm{~cm}$, completamente glabra; raque marrom, cilíndrico, completamente alada, margem inteira, plana; pinas 2,2 $\times 1,6 \mathrm{~cm}$, triangulares a trapeziformes, geralmente dimidiadas, alternas, pinatífidas, lado basiscópico com 1-2 nervuras, lado acroscópico 2-3 dicotomicamente divididas; segmentos lineares, curtos 1-3 $\times 2-4 \mathrm{~mm}$, geralmente terminando com um soro, margem inteira, plana, por vezes ondulada ou levemente crispada; soros distribuídos ao longo de toda a fronde, 1-9 por pina, geralmente de coloração pardacenta em material recém-herborizado; indúsios orbiculares a ovados, com ápice obtuso, não imerso no tecido laminar, base truncada a obtusa, $1,9-2 \times$ 2,1 mm, glabro; receptáculo filiforme ca. $0,8 \times 0,1$ $\mathrm{mm}$, com a região meristemática orbicular.

Material examinado: Castelo, Parque Estadual do Forno Grande, 28.VI.2008, A. Salino et al. 13703 (BHCB); P.H. Labiak et al. 4831 (MBML, UPCB). Divino São Lourenço, Parque Nacional do Caparaó, 10.IX.2008, $A$. Salino et al. 13857 (BHCB); 10.II.2011, F.S. Souza et al.
1466 (BHCB); 6.IV.2011, F.S. Souza \& T.M. Machado 1517 (BHCB). Itaguaçu, Morro do Caparaó, 17.VII.2007, P.H. Labiak 4170 (MBML, UPCB). Marechal Floriano, Sítio Almir Bressan, 21.VII.1988, O.J. Pereira 1647 (VIES). Santa Teresa, Estação Ecológica de Santa Lúcia, 24.II.1996, A. Salino 2627 (BHCB); Reserva Biológica de Nova Lombardia, estrada para Nova Lombardia, 20.II.2002, L. Kollmann et al. 5589 (BHCB, MBML); Reserva Biológica Augusto Ruschi, Trilha da Preguiça, 3.XII.2008, A. Salino et al. 14059 (BHCB).

Material adicional: BRASIL. MINAS GERAIS: Serra do Caparaó, 29.IX.1977, L. Krieger (CESJ).

Ocorre desde o México até o sudeste do Brasil (Stolze 1976), onde é registrada nos seguintes estados: BA, MG, ES, SP, PR, SC e RS (Windisch 2014), como epífita e rupícola em matas úmidas de encosta, porém preferencialmente em matas nebulares, cerca 100-2.000 m alt.

Espécie de grande plasticidade, podendo variar de apenas $2 \mathrm{~cm}$ de tamanho até $15 \mathrm{~cm}$, também no padrão de segmentação da fronde, podendo variar de uma fronde inteira até lobada, pinatífida ou pinatissecta. Espécimes menores de $5 \mathrm{~cm}$ compr. e com pinas simples tem sido tratados no bioma Amazônico como Hymenophyllum brevifrons Kunze ou H. abruptum Hook., porém ainda não foram identificados materiais com estas características no bioma Mata Atlântica.

2. Hymenophyllum caparaoense Brade, Arq. Jard. Bot. Rio de Janeiro 11: 21, t.1. $1951 . \quad$ Fig. 1b Rizoma filiforme, pouco ramificado, , 0,4-0,6 $\mathrm{mm}$ diam., recoberto com tricomas simples, arruivados, 1-1.5 mm compr., pluricelulares, 

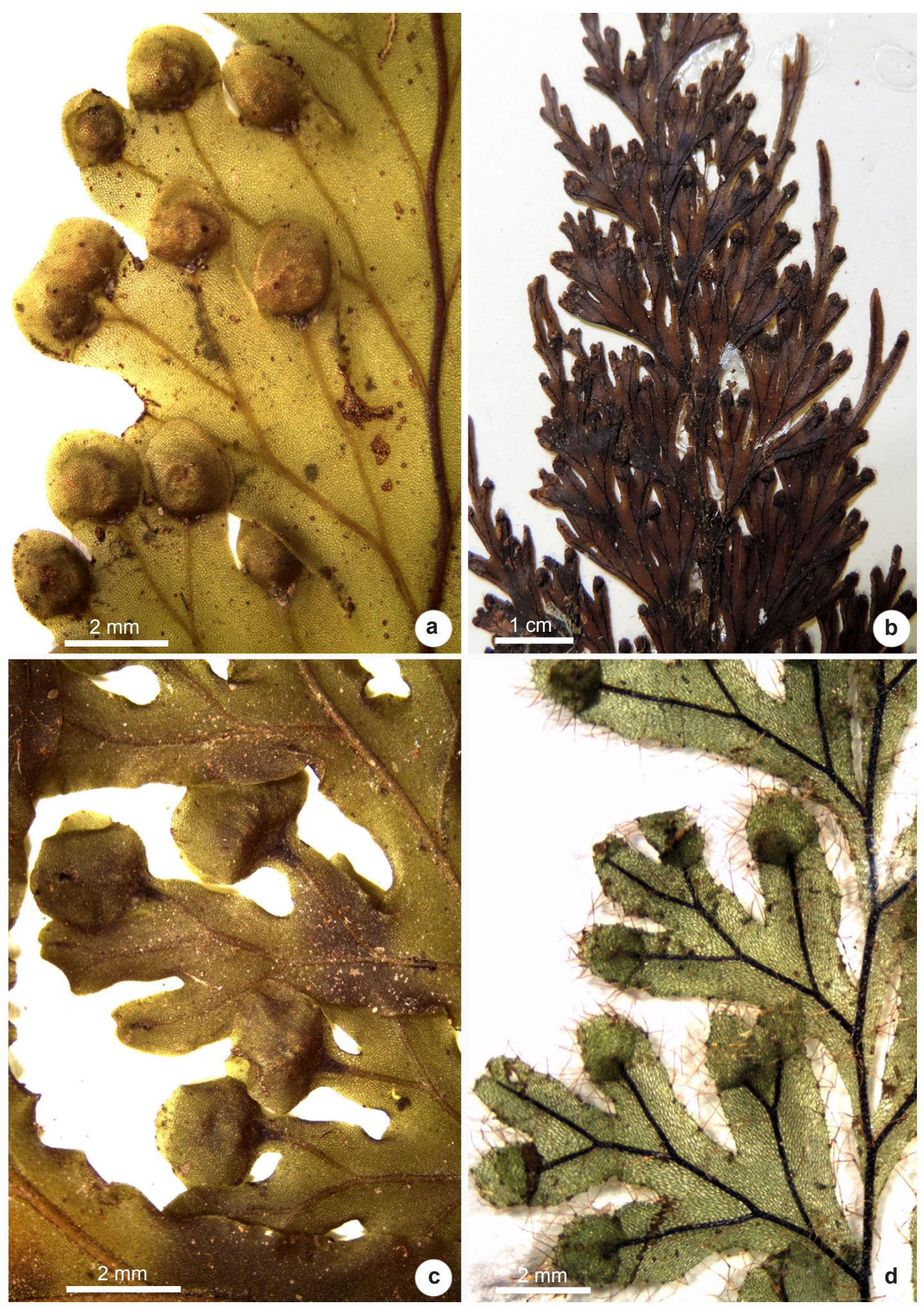

Figura 1 - a. Hymenophyllum asplenioides - segmento fértil. b. H. caparaoense - vista mediana da fronde. c. $H$. caudiculatum - segmentos ondulados e indúsios. d. H. elegans - pinas medianas e indumento.

Figure 1 - a. Hymenophyllum asplenioides - fertile segments. b. H. caparaoense - view of median frond. c. H. caudiculatum - undulated segments and indusium. d. H. elegans - median pinnae and indument. 
adpressos; frondes espaçadas, 7,9-28,5 × 2,5-4 $\mathrm{cm}$, determinadas; estípite marrom, cilíndrico, 0,7 mm diam., 9-11 cm compr., não alado, recoberto de tricomas simples pluricelulares e estrelados; lâmina ovado-lanceolada, 3-pinatífida, (13) 5-17 × 2,5-4 $\mathrm{cm}$, revestida nas margens e nervuras por tricomas simples, furcados, furcado-estrelado ou duas vezes estrelados em ambas as faces; raque marrom, cilíndrico, ca. $0,5 \mathrm{~mm}$ de diam., revestida por tricomas estrelados e duas vezes estrelados, alada principalmente no último terço apical, ala aprox. $0,5 \mathrm{~mm}$ larg., margem inteira, plana e revestida por tricomas furcados ou duas vezes estrelados; pinas lanceoladas, 1-2-pinatífidas, segmentos furcados ou mais divididos em ambos os lados, 2,2-4,2 $\times$ 1,2-1,5 cm, assimétricas, geralmente com a base acroscópica mais desenvolvida, alternas, às vezes um pouco imbricadas, revestida de tricomas nas margens da superfície laminar e sobre as nervuras; segmentos flabeliformes a pinado-pinatífidos, 1,4-2 mm larg., margem inteira, plana, com tricomas simples, furcados ou estrelados; soros em ambas as faces da pina, pouco inclusos, $1 \times$ 0,9 mm, um pouco alongados, um por segmento; indúsios arredondados, fendidos desde a base, base arredondada, imersos no tecido laminar, margem inteira, recoberta por tricomas simples, furcados ou estrelados; receptáculo cilíndrico, capitado, incluso, ca. 0,6 mm, esporângios desenvolvendo-se restritamente no ápice do receptáculo.

Material examinado: BRASIL. MINAS GERAIS: Serra do Caparaó, 9.IX.1941, A.C. Brade 16875 (holótipo RB, isótipos B, CESJ, ICN, NY, SPF, UPCB).

Endêmica das matas nebulares do Parque Nacional do Caparaó (Brade 1951). Erva epífita, a $2.000 \mathrm{~m}$ alt.

Embora o material tipo coletado por A.C.Brade tenha sido registrado na área do Parque pertencente ao estado de Minas Gerais, optou-se por incluí-la na lista, pois provavelmente ocorreu/ ocorre na área de estudo. Após o registro realizado por Brade, a espécie nunca mais foi encontrada em campo, o que sugere que é uma espécie muito rara na área de estudo. Hymenophyllum caparaoense é muito similar a outras espécies do subgênero Sphaerocionium como Hymenophyllum hirsutum, $H$. pulchellum e H. microcarpum, no entanto, difere destas por apresentar caracteres exclusivos, como a ausência de ala no estípite, tricomas furcados ou furcado-estrelados na margem da superfície laminar em ambas as faces da fronde. Por ter sido descrita posteriormente à revisão Neotropical de Sphaerocionum apresentada por Morton (1947), e não ter sido inclusa em trabalhos florísticos, o nome apresenta-se como não resolvido nas bases de dados virtuais, porém, é considerado aqui como um nome válido para a espécie.

3. Hymenophyllum caudiculatum Mart., Icon. Pl. Crypt. 102, tab.67. 1834. Fig. 1c

Rizoma filiforme, ramificado, marrom, 0,5-0,9 mm diam., recoberto por tricomas simples, castanhos, catenados, pluricelulares, ca. 1,3 mm compr., adpressos, abundantes sobre as gemas e rizomas jovens, caducos na maturidade; frondes remotas a contíguas, 7,9-22,5 × 2-7,5 cm, determinadas; estípite marrom claro, cilíndrico, 0,50,9 mm diam., 2,5-6,4 cm compr., completamente alado, ou somente até $1-3 \mathrm{~cm}$ da base (em frondes maiores), decorrente sobre o estípite, ala 0,4-1,2 mm larg., plana ou ondulada; lâmina ovadolanceolada, triangular a elíptica, 3-4-pinatífida, (13-)5-16,5 × 2-7,5 cm, completamente glabra; raque marrom, cilíndrica, alada em toda sua extensão, ala aprox. 1,5 mm larg., margem inteira, às vezes ondulada; pinas ovado-lanceolado, 1-2-pinatífida, 1,4-5,2 × 1-2 cm, simétricas, alternas, por vezes imbricadas; segmentos lineares, 1,5-2 mm larg., margem inteira, às vezes undulada; soros em ambos os lados da pina, ca. 2,6 × 2,2 mm, geralmente mais largos que longos, tecido laminar do segmento fértil com um constrição logo abaixo do soro; indúsios orbiculares a quadriformes, fendidos desde a base, base truncada, não imersa no tecido laminar, margem inteira a irregular, glabro; receptáculo amplo, claviforme a espatulado, complanado, incluso, ca. 1,2 mm compr., 0,3-2 mm larg., esporângios desenvolvendo-se ao longo de todo o receptáculo.

Material examinado: Castelo, Parque Estadual do Forno Grande, 28.VI.2008, A. Salino et al. 13694 (BHCB); 13.II.2008, P.H. Labiak et al. 4577 (MBML, UPCB). Divino de São Lourenço, Parque Nacional do Caparaó, RPPN Águas do Caparaó, Cachoeira Alta, 12.IX.2008, A. Salino et al. 13887 (BHCB); Parque Nacional do Caparaó, Rio do Veado, 10.II.2011, F.S. Souza et al. 1444 (BHCB). Fundão, Goipabo-açu, 3.V.2003, A.P. Fontana \& R.C. Britto 569 (BHCB, MBML). Iúna, Parque Nacional do Caparaó, Região da Cachoeira Bonita, F.S. Souza et al. 1235 (BHCB); Serra do Valentim, propriedade do Senhor Aristides, 4.VI.2004, J.P.F. Zorzanelli 1018 (BHCB). Santa Teresa, Reserva Biológica de Santa Lúcia, 6.IX.1993, G.M.F.V. Aquije \& E. Bausen 191 (BHCB, MBML); 26.IX.1993, G.M.F.V. Aquije \& E. Bausen 171 (BHCB, MBML); 26.IX.1993, G.M.F.V. Aquije \& E. Bausen 175 (BHCB, MBML); 24.II.1996, A. Salino 2628 (BHCB); 3.IX.1998, L. Kollmann et al. 458 (MBML); 
Valsugana Velha, propriedade particular do Leomir, 14.VI.2000, V. Demuner et al. 1127 (BHCB); Reserva Biológica Augusto Ruschi, 17.VII.2002, R.R. Vervloet et al. 492 (BHCB, MBML); 21.VIII.2002, G.M.F.V. Aquije et al. 341 (BHCB , MBML); 6.II.2003, R.R. Vervloet et al. 1791 (BHCB, MBML); 12.VII.2003, J. Rossini et al. 416 (MBML); 2.XII.2008, A. Salino et al. 14038 (BHCB); 22.VIII.2012, T.B. Flores \& G.O. Romão 1060 (RB, foto!). Serra, Reserva Biológica Mestre Álvaro, 24.VI.1989, O.J. Pereira 2080 (VIES).

Ocorre disjuntamente no sul do Chile e Argentina e na Mata Atlântica, onde é registrada nos seguintes estados: BA, MG, ES, SP, PR, SC e RS (Windisch 2014). Epífita, rupícola ou terrícola em locais sombreados e muito úmidos, tais como margens de regatos em florestas de encosta, barrancos úmidos de matas ciliares, ou matas nebulares, cerca 300-2.000 m alt.

Espécie de ampla distribuição geográfica e plasticidade ecológica, podendo variar amplamente no tamanho, padrão de segmentação da fronde e no formato dos indúsios. Larsen et al. (2013) discute a possibilidade de as populações do sul austral comporem um táxon distinto das populações ocorrentes na Mata Atlântica, devido a alguns caracteres como a ala do estípite, e espessura do rizoma, porém, ainda se necessitam de mais detalhamento morfológico para sustentar tal segregação.

4. Hymenophyllum elegans Spreng., Syst. Veg., ed. 16, 4(1):133. $1827 . \quad$ Fig. 1d

Rizoma filiforme, ramificado, castanho, 0,1-0,2 mm diam., recoberto por tricomas simples arruivados, cilíndricos, multicelulares (ca. 5 cel.), 0,8-1,5 mm compr., patentes, densos, principalmente sobre os meristemas; frondes agrupadas ou curto distanciadas, 1,8-8,2 × 0,92,2 cm; estípite castanho escuro a nigrescente, cilíndrico, 0,1-0,2 mm diam., 1,1-9,4 mm compr., não alado ou estreitamente alado no ápice, recoberto por tricomas simples, estipitado-furcados ou eventualmente estrelados, com três a quarto raios, ca. 0,9 mm compr.; lâmina linear a lanceolada, 1-pinado-pinatífida na base, ápice pinatífido, $1,7-7,7 \times 0,9-2,2 \mathrm{~cm}$, pilosa, tricomas sobre raque, nervuras e bordos da superfície laminar, tricomas simples, 1-4-furcados na base, furcados ou estrelados, pardacentos; raque cilíndrica, castanho escura a nigrescente, lustrosa, alada a partir do último terço distal ou com ala curta proveniente da base decorrente das pinas, recoberta por tricomas furcados ou estrelados, raramente com tricomas simples unicelulares ou bicelulares; pinas ovadas ou lanceoladas, sésseis e adnatas à raque no lado acroscópico, 3-10 segmentos cada, 1,2 × 1,1 cm, simétricas; segmentos lineares, simples, por vezes furcados, 1,6-1,9 mm larg., ápice arredondado, margem inteira, plana, recoberta por tricomas na margem; soros em ambos os lados da pina, orbiculares, ca. $1 \times 1 \mathrm{~mm}$; indúsios orbiculares, recobertos nas margens por tricomas simples, furcados ou estrelados, base imersa no tecido laminar; receptáculo filiforme, cilíndrico, ca. 0,3 $\mathrm{mm}$, imerso, ca. de até 20 esporângios.

Material examinado: Castelo, Parque Estadual Forno Grande, 28.VI.2008, A. Salino et al. 13691 (BHCB). Divino de São Lourenço, Parque Nacional do Caparaó, RPPN Águas do Caparaó, Cachoeira Alta, 12.IX.2008, A. Salino et al. 13878 (BHCB). Santa Teresa, Reserva Biológica Augusto Ruschi, Nova Lombardia, 5.XI.2002, J. Rossini et al. 121 (MBML); 23.III.2003, R.R. Vervloet et al. 2046 (BHCB, MBML); 13.VII.2007, P.H. Labiak et al. 4088 (MBML, UPCB ). São Roque do Canaã, Alto Misterioso, 13.VII.2007, P.H. Labiak et al. 4101 (MBML); P.H. Labiak 4114 (MBM).

Material adicional: BRASIL. MINAS GERAIS: Simonésia, RPPN Mata do Sossego, 17.XI.2013, T. Almeida et al. 3361 (BHCB).

Ocorre no Neotrópico, desde a Guatemala até a Mata Atlântica (Morton 1947; Stolze 1976), onde ocorre nos seguintes estados: BA, ES, MG, RJ, $\mathrm{SP}$ e PR. Epífita ou rupícola, em matas úmidas de encosta, galeria e nebulares, cerca 700-2.000 m alt.

Espécie muito variável dentro da área geográfica onde ocorre, podendo apresentar distintas combinações quanto ao padrão de segmentação da fronde e da composição dos tricomas, porém, a presença de tricomas somente na raque, nervuras e margem da superfície laminar, juntamente a base da fronde pinada com as pinas adnatas à raque são características diagnósticas da espécie.

5. Hymenophyllum fragile (Hedw.) C.V.Morton, Contr. U.S. Natl. Herb. 29(3): 172. 1947. Fig. 2a

Rizoma filiforme, ramificado, marrom, 0,1-0,2 mm diam., tricomas pardacentos, simples, multicelulares, ca. 0,5 mm compr., patentes, abundantes; frondes contíguas, 4,5-8,2 × 1,5-2,4 $\mathrm{cm}$, lineares a lanceoladas, recobertas por tricomas em todas as estruturas; estípite marrom, cilíndrico, 0,1 mm diam., 0,5-1,9 cm compr., alado somente no ápice, recoberto por tricomas simples, furcados e estrelados, ca. 0,4 mm compr.; lâmina linear, 1-pinado-pinatífida, 3,9-7 × 1,5-2,4 cm, recoberta em toda as superfícies (raque, lamina e nervuras) por tricomas estrelados, ou duas ou três vezes mais 

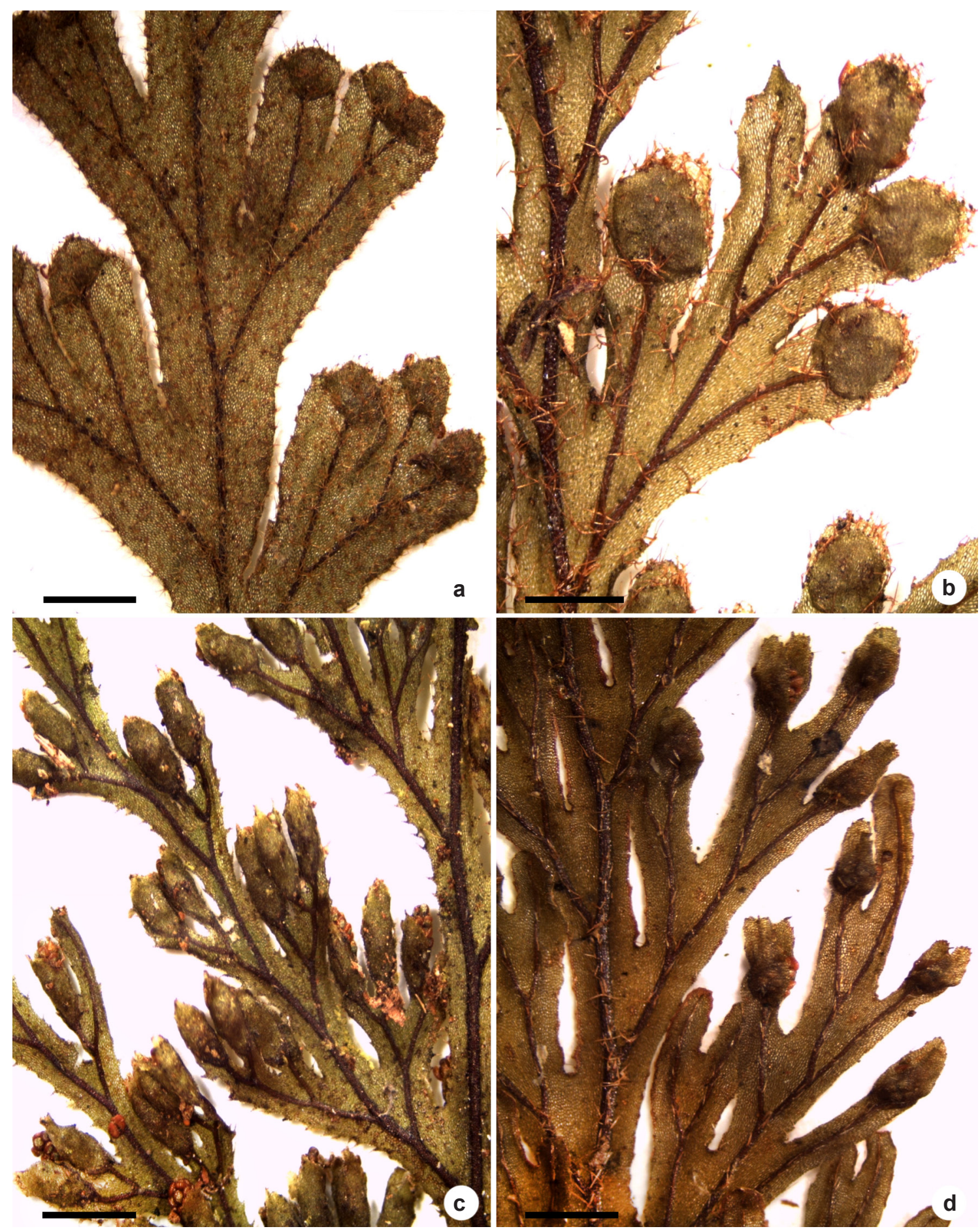

Figura 2 -a. Hymenophyllum fragile - pina mediana e indumento. b. H. hirsutum-indumento e indúsios. c. H. magellanicum - segmentos ciliados e indúsio tubuloso. d. H. microcarpum - indumento e indúsios alongados. Barras: $2 \mathrm{~mm}$ Figure 2 - a. Hymenophyllum fragile - median pinnae and indument. b. H. hirsutum - indument and indusium shape. c. H. magellanicum - ciliate segments and tubulose indusium. d. H. microcarpum - indument and elongate indusium. Bars: $2 \mathrm{~mm}$ 
decompostos, de diferentes comprimentos, desde sésseis a $1 \mathrm{~mm}$; raque pardacenta, cilíndrica, alada em toda a extensão, ca. 1,1 mm larg., margem inteira, raque e ala recobertas por tricomas estrelares pardacentos; pinas furcadas, flabeliformes a pinatífidas, 1-5 segmentos, as basais mais divididas, as apicais flabeliformes, 1,3 × 1,2 cm, simétricas; segmentos simples, lineares, até 2,2 mm de larg., ápice arredondado, bordo inteiro, plano, margem e superfície laminar recobertos por tricomas estrelados sésseis, a curto estipitados, cel. basal com até 0,1 mm comp.; soros em ambos os lados da pina, um por segmento; indúsios orbiculares, $0,9 \times 1,2$ $\mathrm{mm}$, base truncada, não ou pouco imersos no tecido laminar, recobertos por tricomas estrelados como os da lâmina; receptáculo filiforme, cilíndrico, imerso, ca. 0,6 mm compr., com inúmeros esporângios.

Material examinado: Castelo, Parque Estadual do Forno Grande, 13.II.2008, P.H. Labiak et al. 4590 (MBML); 26.VI.2008, A. Salino et al. 13663 (BHCB); 28.VI.2008, A. Salino et al. 13688 (BHCB); 18.VII.2008, P.H. Labiak et al. 4824 (MBML, UPCB); 15.X.2008, P.H. Labiak 4960 (MBML, UPCB). Braço do Sul, 14.VIII.1948, A.C. Brade 19426 (ICN, RB, foto!). Divino de São Lourenço, Parque Nacional do Caparaó, RPPN Águas do Caparaó, Cachoeira Alta, 12.X.2008, A. Salino et al. 13854 (BHCB); Parque Nacional do Caparaó, Rio do Veado, Pedra Escorada, 10.II.2011, F.S. Souza et al. 1448 (BHCB). Domingos Martins, São Paulo do Aracê, entorno do Parque Estadual da Pedra Azul, 6.XII.2008, A. Salino et al. 14175 (BHCB). Iúna, Parque Nacional do Caparaó, região da Cachoeira Bonita, 3.XII.2010, V. Demuner et al. 1238 (BHCB); trilha para o Poço dos Desejos e Cemitério dos Jesuítas, 12.V.2011, F.S. Souza et al. 1544 (BHCB). Santa Teresa, Reserva Biológica Augusto Ruschi, 16.VII.2002, R.R. Vervloet 476 (BHCB, MBML); 25.II.2003, R.R. Vervloet et al. 1921 (BHCB, MBML, UPCB). Sem município, Limoeiro, Santa Maria, 17.V.1946, A.C. Brade 18294 (CESJ, RB, HUCS).

Material adicional: BRASIL. MINAS GERAIS: Espera Feliz, Parque Nacional do Caparaó, região de Pedra Menina, Macieira e estrada descendo para a portaria do Parque, 25.XI.2006, A. Salino et al. 11489 (BHCB).

Ocorre no Neotrópico, desde o México até a Mata Atlântica (Morton 1947; Stolze 1976), onde ocorre nos seguintes estados: BA, ES, MG, RJ, $\mathrm{SP}, \mathrm{PR}, \mathrm{SC}$, RS. Epífita ou rupícola em paredões húmidos ou troncos de árvores em locais úmidos e sombreados de florestas ciliares, de encosta e nebulares, cerca 150-2.000 m alt.

Espécie muito próxima a Hymenophyllum venustum por compartilhar muitos caracteres como a distribuição dos tricomas em todas as estruturas foliares e por ocorrerem no mesmo hábitat, porém, podem ser diferenciadas pelos segmentos em geral flabeliformes (mais detalhes em $H$. venustum). Também é próxima a Hymenophyllum angustum Bosch, da qual, segundo Morton (1947), distinguese pelo tamanho das frondes (5-20 vezes mais longas que largas em $H$. angustum e 5-7 vezes em H. fragile) porém, esta delimitação ainda é confusa e duvidosa, já que ambas ocorrem simpatricamente no bioma Amazônico.

6. Hymenophyllum hirsutum (L.) Sw., J. Bot. (Schrader) 2: 99. 1800.

Fig. $2 b$

Rizoma filiforme, ramificado, marrom, ca. 0,3 $\mathrm{mm}$ de diam., recoberto por tricomas simples de ca. 1,4 mm compr., pluricelulares (4-7 células), pardacentos a arruivados, patentes, raízes finas e abundantes; frondes remotas a contíguas, 5,6-14,5 $\times$ 1,5-3 cm; estípite castanho, cilíndrico, 0,4 mm diam., 1,4-4,1 cm compr., alado até a base, recoberto de tricomas simples, furcados, estrelados, ala decorrente ao longo do estípite, até 1,1 mm larg., plana, recoberta de tricomas furcados ou furcadoestrelados na margem; lâmina elíptica a lanceolada, 1-2-pinado-pinatífida, 5,1-10,5 × 1,5-3 cm, determinada, pilosa, recoberta de tricomas sobre a margem da superfície laminar, raque e nervuras, tricomas simples, furcados na base, estrelados, ou duas vezes furcado-estrelados; raque castanho escura, cilíndrica, alada em toda sua extensão, margem inteira, por vezes pontuada na inserção dos tricomas, plana, recoberta por tricomas na margem; pinas triangulares, pinatífidas a pinadopinatífidas, $2 \times 1,1 \mathrm{~cm}$, simétricas, adnatas à raque, alternas; segmentos lineares, geralmente simples, os proximais por vezes mais decompostos, ca. 2 $\mathrm{mm}$ larg., ápice arredondado, planos a corrugados quando secos; soros em ambos os lados da pina, ca. 1,3 $\times 1,3 \mathrm{~mm}$, terminais, um por segmento, com base imersa no tecido laminar; indúsios orbiculares, fendidos na metade superior, base obtusa a arredondada, margem inteira, recoberta por tricomas simples, furcados ou estrelados; receptáculo filiforme, cilíndrico a capitado, incluso, ca. 0,4 mm, com inúmeros esporângios.

Material examinado: Alfredo Chaves, São Bento de Urânia, 10.VIII.1994, G. Hatschbach \& J.M. Silva 61200 (MBM). Castelo, Parque Estadual do Forno Grande, 12.II.2012, P.H. Labiak et al. 4552 (MBML); 26.VI.2008, A. Salino 13665 (BHCB). Divino de São Lourenço, Parque Nacional do Caparaó, RPPN Águas do Caparaó, Cachoeira Alta, 12.VIII.2008, A. Salino et al. 13891 (BHCB); Parque Nacional do Caparaó, Rio do Veado, 10.II.2011, F.S. Souza et al. 1450 (BHCB); F.S. Souza et al. 1465 (BHCB); Pedra Escorada, 6.IV.2011, F.S. 
Souza \& T.M. Machado 1516(BHCB); F.S. Souza \& T.M. Machado 1518 (BHCB). Domingos Martins, São Paulo do Aracê, 6.XII.2008, A. Salino et al. 14174 (BHCB). Itaguaçu, Morro do Caparaó, 17.VII.2007, P.H. Labiak et al. 4169 (MBML). Santa Teresa, trilha que sobe a encosta ao lado da entrada do Country Club, 25.II.1996, A. Salino 2654 (BHCB); Reserva Biológica Augusto Ruschi, Nova Lombardia, 2.IX.2003, J. Rossini et al. 510 (MBML); Trilha da Cachoeira, 2.XII.2008, A. Salino et al. 13980 (BHCB); A. Salino et al. 13981 (BHCB); 4.XII.2008, A. Salino et al. 14084 (BHCB). São Roque do Canaã, Alto Misterioso, 13.VII.2007, P.H. Labiak 4214 (MBML).

Ocorre na América Tropical, desde o México e Cuba, até o bioma Mata Atlântica (Morton 1947; Stolze 1976), onde ocorre nos seguintes estados: CE, PE, BA, ES, MG, RJ, SP, PR, SC, RS. Epífita ou rupícola em locais úmidos e sombreados, em florestas de encosta e nebulares, cerca 500-2.000 $\mathrm{m}$ alt.

Hymenophyllum hirsutum é uma espécie de ampla distribuição geográfica e consequente variação fenotípica, sendo considerada por muitos autores como várias espécies distintas [H. caulopteron Fée, H. gardnerianum Sturm, H. ulei Christ \& Giesenh., H. vestitum (C.Presl) Bosch]. Lellinger (1991) considerou todo o material ocorrente no bioma Mata Atlântica como Hymenophyllum vestitum devido ao maior tamanho das frondes destas populações, o que foi endossado por Windisch (2014) no detalhamento das espécies ocorrentes no estado do Rio Grande do Sul. Mesmo dentro do bioma Mata Atlântica percebe-se uma ampla plasticidade no tamanho das frondes, tamanho do estípite e sua ala, principalmente entre as populações ocorrentes na Região Sul, até São Paulo e Rio de Janeiro com as populações ocorrentes em Minas Gerais, Espírito Santo, Bahia e Pernambuco. No entanto, a presença de materiais com caracteres intermediários aos indicados por Lellinger (1991) para a separação de Hymenophyllum hirsutum de H. vestitum dificulta a delimitação das espécies, e portanto foram consideradas aqui como um único táxon de senso amplo.

\section{Hymenophyllum magellanicum (Desv.) Willd.} ex Kunze, Bot. Zeitung 5: 226. $1847 . \quad$ Fig. 2c

Rizoma filiforme, ramificado, castanho escuro, 0,6 $\mathrm{mm}$ diam., recoberto por tricomas simples ou furcados, sobre uma célula basal alargada, pardacentos, adpressos, 0,8-1,3 $\mathrm{mm}$ compr.; frondes remotas, 8-10,6 × 3,6-6,9 cm, glabras em ambas as faces; estípite castanho escuro, cilíndrico, 0,6-0,8 mm diam., 2,6-4,2 cm compr., alado em toda a sua extensão, glabro, recoberto somente na base com tricomas semelhantes ao do rizoma, ala ondulada, de margem erosa a esparso ciliada, ca. $1 \mathrm{~mm}$ larg.; lâmina ovada a triangular, 3-pinado-pinatífida, 6,4 × 3,6-6,9 cm, encurvada, glabra; raque castanho escura, cilíndrica, alada em toda sua extensão, ala ciliada, ondulada, ca. 0,5 mm larg.; pinas lanceoladas a ovadas, 2-pinado-pinatífida, 3,6 × 1,6 cm, simétricas, alternas; segmentos lineares, 0,8-1 mm larg., ápice emarginado, margem ciliada, plana; soros em ambas as faces da pina, um por segmento, no plano da superfície laminar, tubulares, ca. $2 \times 0,8 \mathrm{~mm}$; indúsios alongados, oblongos, base aguda, imersa no tecido laminar, ápice agudo, margem ciliada, valvas abertas no último terço distal; receptáculo filiforme, cilíndrico, projetando-se para fora dos indúsios, inúmeros esporângios desenvolvendo-se ao longo de todo o receptáculo.

Material examinado: Sem município, Parque Nacional do Caparaó, Cachoeira Bonita, 4.XI.2010, F.S. Souza et al. 1145 (BHCB). Iúna, Parque Nacional do Caparaó, região da Cachoeira Bonita, 3.XII.2010, F.S. Souza et al. 1232 (BHCB); Cachoeira Bonita, 16.09.2016, A. Salino 16247 (BHCB). Sem município, Serra do Caparaó, X.1941, A.C. Brade (ICN). Sem município, SE slope of Serra do Caparaó, Y.E.J. Mexia 4069 (NY00807912, foto!).

Material adicional: BRASIL. MINAS GERAIS: Parque Nacional do Caparaó, C. Bonita, 15.X.1988, M.C. Brügger et al. (CESJ 23517).

Ocorre no Chile, Argentina e Brasil (Larsen et al. 2013; Windisch 2014), onde ocorre nos seguintes estados: ES, MG, RJ, SP, PR, SC, RS. Epífita, rupícola e humícola em matas nebulares a cerca 950-2.500 m. alt.

8. Hymenophyllum microcarpum Desv., Mém. Soc. Linn. Paris 6: 333. $1827 . \quad$ Fig. 2d

Rizoma robusto, pouco ramificado, marrom, 0,7-0,9 mm diam., recoberto por tricomas castanho claros, ca. 1,5 mm compr., simples, pluricelulares (5-8 células), adpressos a patentes, caducos na maturidade; frondes remotas, 19-24 × 6-10,6 $\mathrm{cm}$; estípite castanho escuro, cilíndrico, $0,8 \mathrm{~mm}$ diam., 8,2-10 cm compr., recoberto por tricomas pluricelulares, simples ou estrelados, alado no ápice, ala decorrente sobre o estípite ca. 1-2,4 cm, ala 0,5-0,6 mm larg., margem inteira ou pontuada, tricomas simples, furcados ou estrelados restritos à margem; lâmina ovada, 3-4-pinado-pinatífida, $10,5-15,5 \times 6-10,6 \mathrm{~cm}$, pilosa somente na face adaxial, face abaxial com tricomas restritos à base da raque; raque castanho escura, cilíndrica, alada em toda a extensão, margem inteira, com 
tricomas pluricelulares simples ou furcados, plana; pinas ovadas a lanceoladas, 4,6-6,5 × 1-2,2 cm, 1-2-pinado-pinatífida, simétricas, alternas, as basais arqueadas para o ápice, adnatas à raque, tricomas simples, furcados e estrelados restritos às nervuras da face adaxial; segmentos lineares, $0,6-1,1 \mathrm{~mm}$ larg., ápice arredondado, planos, margem inteira, recoberta por tricomas simples adpressos, 1-2 celulares restritos à margem da superfície laminar; soros em ambos os lados da pina, um por segmento; indúsios lanceolados, não ou pouco imerso na base, base aguda, ápice agudo, margem erosa, por vezes ciliada, com tricomas simples, valvas abrindo-se até a base; receptáculo filiforme, cilíndrico, incluso até a metade do comprimento do indúsio, ca. $0,6 \mathrm{~mm}$ compr., com 10-30 esporângios se desenvolvendo ao longo de todo o receptáculo.

Material examinado: Castelo, 12.VIII.1948, A.C. Brade 19239 (CESJ, RB, foto!); Parque Estadual Forno Grande, 28.VI.2008, A. Salino 13708 (BHCB). Divino de São Lourenço, Parque Nacional do Caparaó, Pedra Escorada, 6.IV.2011, F.S. Souza \& T.M. Machado 1519 (BHCB). Iúna, Serra do Valentim, 1.XII.2013, J.P.F. Zorzanelli \& L. Bacci 889 (BHCB, VIES).

Material adicional: BRASIL. MINAS GERAIS: Espera Feliz, Parque Nacional do Caparaó, região de Pedra Menina, Macieira e estrada descendo para a portaria do Parque, 25.XI.2006, A. Salino et al. 11488 (BHCB).

Ocorre no Neotrópico, desde as Antilhas até o sudeste e parte do sul do Brasil (Morton 1947; Stolze 1976), onde ocorre nos seguintes estados: ES, MG, RJ, SP, PR e SC. Epífita ou rupícola em florestas úmidas e nebulares, cerca de 800-2.000 $\mathrm{m}$ alt.

\section{Hymenophyllum myriocarpum Hook., Sp. Fil.} 1: 106, t.37d. 1844.

Fig. 3a

Rizoma robusto, ramificado, pardacento, 0,3-0,5 mm diam., tricomas castanhos, simples, pluricelulares, 1-1,7 mm compr., adpressos, escassos, principalmente nos rizomas maduros; frondes remotas, $13,1-23,5 \times 4,3-8,0 \mathrm{~cm}$; estípite pardacento, cilíndrico, 0,4-0,6 mm diam., 2,85-7.5 cm compr., recoberto na base com tricomas semelhantes aos do rizoma, alada até $3 / 4$ superior, ala plana, $0,1-0,2 \mathrm{~mm}$ larg., decorrente sobre o estípite; lâmina lanceolada a ovada, 3-4-pinado-pinatífida, $10,3-16 \times 4,3-8 \mathrm{~cm}$, recoberta na face adaxial por tricomas glandulares; raque castanha, cilíndrica, alada em toda sua extensão, $0,3-0,5 \mathrm{~mm}$, margem inteira, plana, recoberta com esparsos tricomas glandulares, 1-2 celulares; pinas lanceoladas a triangulares, 1-2-pinado-pinatífidas, ca. 5,5 × 2,3 $\mathrm{cm}$, simétricas, alternas, ascendentes; segmentos lineares ou flabelados, 1,1-1,8 mm larg., ápice emarginado, margem inteira, plana, nervuras com tricomas 1-2 celulares, capitados e nigrescentes na face adaxial; soros em ambos os lados da pina, globosos, por vezes mais largos que longos, 1,5 $\times 1,5 \mathrm{~mm}$, desenvolvendo-se sobre um segmento simples com uma constrição no tecido laminar abaixo do soro; indúsios orbiculares, amplos, por vezes imbricados, não imersos no tecido laminar, fendidos até a base, base e ápice arredondado, margem inteira; receptáculo filiforme, cilíndrico a clavado, incluso, ca. $0,5 \times 0,3 \mathrm{~mm}$, com ca. de 15-30 esporângios.

Material examinado: Castelo, Parque Estadual do Forno Grande, 5.IX.2004, L. Kollmann \& R.M. Kollmann 7018 (MBML); 18.VII.2007, P.H. Labiak et al. 4234 (MBML, UPCB, HUCS).

Material adicional: BRASIL, MINAS GERAIS: Baependi, Parque Estadual da Serra do Papagaio, 21.III.2015, V.A.O. Dittrich 1989 (CESJ).

Ocorre na América Tropical, desde o México até o sudeste do Brasil (Stolze 1976), onde ocorre nos seguintes estados: BA, MG, ES, RJ, SP. Epífita em florestas úmidas de encosta e matas nebulares, acima de $1.000 \mathrm{~m}$ alt.

Espécie geralmente confundida com Hymenophyllum polyanthos nas coleções de herbário, da qual difere pela presença de tricomas glandulares 1-2 celulares sobre as nervuras da pina e segmentos da face adaxial. A disposição dos soros sobre um segmento alongado e simples também é uma característica diagnóstica para a espécie, assim como os indúsios orbiculares, geralmente mais largos do que longos. A espécie é pouco amostrada dentro do bioma Mata Atlântica, o que dificulta a delimitação correta de sua área de distribuição.

10. Hymenophyllum plumosum Kaulf., Enum. Filic. 267. 1824.

Fig. 3b

Rizoma longo reptante, filiforme, ramificado, pardacento, 0,5-0,7 $\mathrm{mm}$ diam., recoberto por tricomas ruivos, filiformes, simples, por vezes dendríticos, pluricelulares, $2-3 \mathrm{~mm}$, patentes; frondes contíguas, $20-37 \times 3-4,5 \mathrm{~cm}$; estípite castanho claro, cilíndrico, 0,5-0,7 $\mathrm{mm}$ diam., $1,9-5,4 \mathrm{~cm}$ compr., por vezes parecendo mais longo pela decomposição das pinas mais velhas, não alado, piloso, recoberto por uma mescla de tricomas simples, principalmente na base, e tricomas estrelados e dendríticos, glabrescentes na maturidade; lâmina linear, pinada-pinatífida, $15-35 \times 3-4,5 \mathrm{~cm}$, pilosa, densamente recoberta por tricomas estrelados e dendríticos; raque castanho clara a pardacenta, cilíndrica, não alada, totalmente 

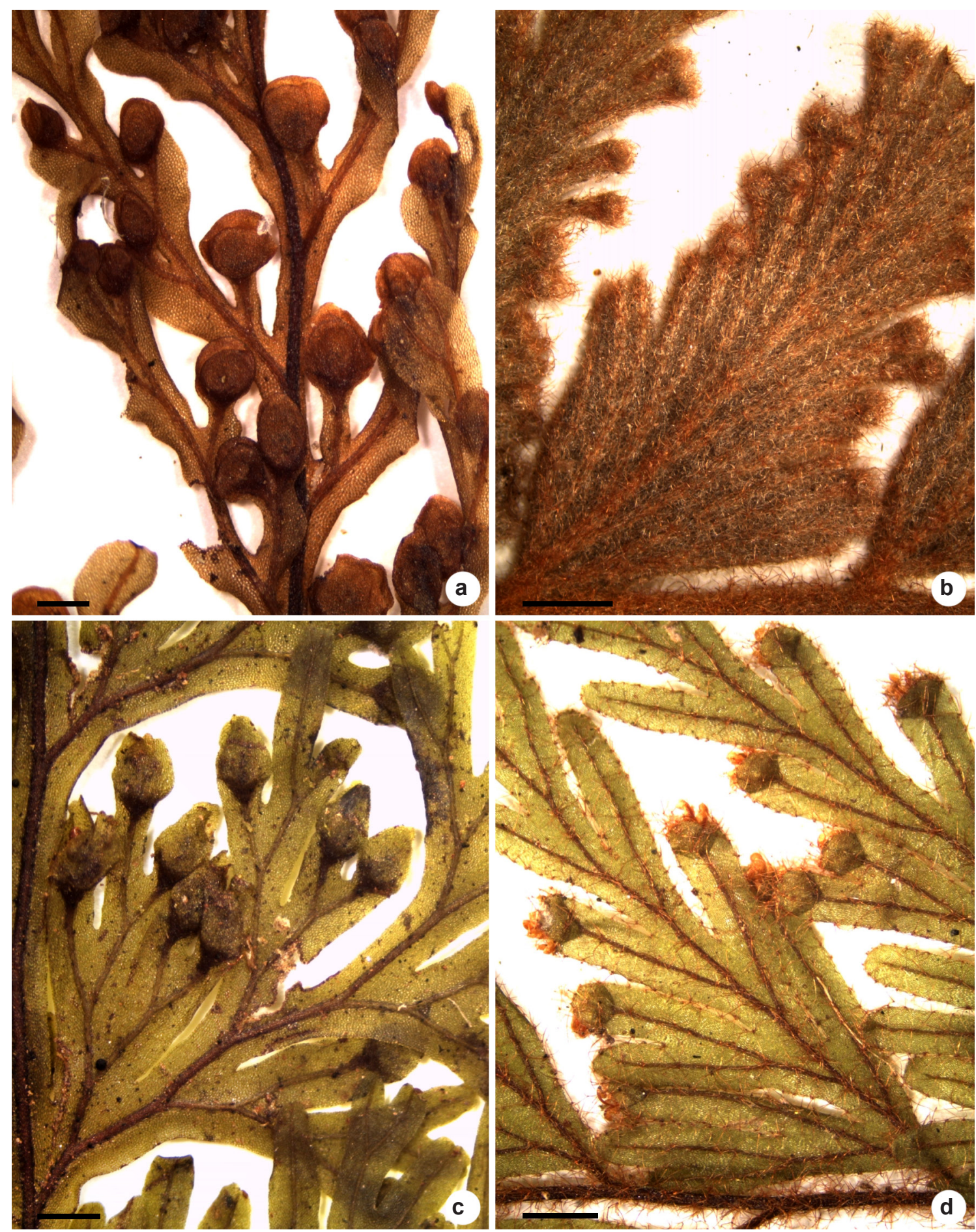

Figura 3 - a. Hymenophyllum myriocarpum - segmentos férteis. b. H. plumosum - indumento. c. H. polyanthos segmentos. d. H. pulchellum - indumento e segmentos férteis. Barras: $1 \mathrm{~mm}$

Figure 3 - a. Hymenophyllum myriocarpum - detail of fertile segment. b. H. plumosum - details of laminar tissue indument. c. $H$. polyanthos - fertile segments. d. H. pulchellum - indument and fertile segments. Bars: $1 \mathrm{~mm}$ 
recoberta por tricomas iguais aos da lâmina; pinas triangulares a trapeziformes, pinatífidas, alguns segmentos proximais bífidos, $4 \times 1,1$ $\mathrm{cm}$, simétricas, alternas, ascendentes; recobertas densamente por tricomas estrelados, biestrelados ou dendríticos, pluricelulares, ruivos, sobre as nervuras e superfície laminar em ambas as faces da pina, nervuras com expansões laminares, ca. $0,05-0,1$ $\mathrm{mm}$, em ambas as faces; segmentos lineares, $0,5-0,7$ $\mathrm{mm}$ larg., planos, margem inteira, geralmente terminando em um soro; soros em ambos os lados da pina, globosos, $0,7 \times 0,7 \mathrm{~mm}$; indúsios orbiculares, não imersos no tecido laminar, fendidos até a base, base e ápice arredondados, margem inteira, densamente revestidos por tricomas iguais aos da lâmina; receptáculo cilíndrico, filiforme, incluso, ca. 0,5 mm, contendo ca. de 20-30 esporângios.

Material examinado: Divino de São Lourenço, Parque Nacional do Caparaó, Rio do Veado, Pedra Escorada, 10.II.2011, F.S. Souza et al. 1454 (BHCB). Iúna, Parque Nacional do Caparaó, trilha para o Poço dos Desejos e Cemitério dos Jesuítas, F.S. Souza et al. 1545 (BHCB). Sem município, SE slope of Serra da Caparaó, Y.E.J. Mexia 4051 (NY00807934, foto!).

Material adicional: BRASIL. MINAS GERAIS: Lima Duarte, Parque Estadual de Ibitipoca, Cachoeira dos Macacos, à direita descendo o Rio do Salto, 15.V.1993, R.F. Novelino et al. 1050 (CESJ). Sem município, Serra do Caraça, Parque Natural, acima da Cascatinha, 23.X.1993, A. Salino 4983 (BHCB).

Ocorre no Neotrópico, desde a Costa Rica até o sudeste do Brasil (Morton 1947; Tryon \& Stolze 1989), onde ocorre nos seguintes estados: MG, ES, RJ, SP e PR. Epífita, terrícola ou rupícola em afloramentos rochosos, em florestas de encosta ou nebulares, cerca 800-2.500 m alt.

Espécie muito próxima de Hymenophyllum pulchellum e H. rufum. De Hymenophyllum pulchellum pode ser facilmente diferenciada pela presença dos tricomas sobre as nervuras e superfície laminar, que em $H$. pulchellum estão restritos somente às margens e nervuras. De Hymenophyllum rufum, difere pela presença das expansões laminares sobre as nervuras em ambas as faces, mais evidentes em pinas senescentes, ou pela remoção dos tricomas.

11. Hymenophyllum polyanthos (Sw.) Sw., J. Bot. (Schrader) 2: 101. 1800. Fig. 3c

Rizoma filiforme, ramificado marrom, $0,2-0,5 \mathrm{~mm}$ diam., revestido por esparsos tricomas simples, castanhos, até $1,3 \mathrm{~mm}$ compr., adpressos, caducos na maturidade; frondes contíguas, 3,4-18,5 $\times 1-6,2 \mathrm{~cm}$; estípite castanho, cilíndrico, $0,2-0,7$ mm de diam. 0,7-7,3 cm compr., com esparsos tricomas iguais aos do rizoma, alado em toda a extensão, ala plana, ca. 0,1-0,3 mm; lâmina oblonga a triangular, 3-4-pinado-pinatífida, 2,2-12 × 1-6,2 $\mathrm{cm}$, glabra em toda a superfície; raque castanha, cilíndrica, completamente alada, ala plana ou ondulada, margem da ala inteira; pinas ovadas a lanceoladas, 2-3-pinado-pinatífidas, 0,8-4,6 $\times$ 0,5-2,2 cm, simétricas, alternas; segmentos curto lineares a flabeliformes, 0,7-1,1 mm larg., ápice emarginado, margem inteira, plana ou levemente ondulada; soros em ambos os lados da pina, um por segmento; indúsios orbiculares, ovados ou triangulares, imersos até a metade ou não, até $1,8 \times 1,3 \mathrm{~mm}$, fendidos até a metade ou até a base, base truncada, aguda ou arredondada, ápice arredondado, agudo ou cuneado, margem inteira, glabra; receptáculo filiforme, incluso ou exserto, ca. de $0,4-0,8 \mathrm{~mm}$ compr., com inúmeros esporângios. Material examinado: Castelo, Parque Estadual Forno Grande, 28.VI.2008, A. Salino et al. 13685 (BHCB). Divino de São Lourenço, Parque Nacional do Caparaó, Pedra Escorada, 6.V.2011, F.S. Souza \& T.M. Machado 1509 (BHCB). Domingos Martins, São Paulo do Aracê, entorno do Parque Estadual da Pedra Azul, 6.XII.2008, A. Salino et al. 14191 (BHCB). Ibitirama, Parque Nacional do Caparaó, base de Pedra Roxa, 13.IX.2008, A. Salino et al. 13920 (BHCB). Itaguaçu, Morro do Caparaó, 17.VII.2007, P.H. Labiak 4174 (MBML). Iúna, Parque Nacional do Caparaó, região da Cachoeira Bonita, 3.XII.2010, F.S. Souza 1236 (BHCB). Santa Teresa, 28.IX.1993, G.M.F.V. Aquije et al. 203 (MBML); G.M.F.V. Aquije et al. 205 (MBML); Estação Biológica de Santa Lúcia, 26.VIII.1993, G.M.F.V. Aquije 146 (MBML); 24.II.1996, A. Salino 2625 (BHCB); 4.III.1997, A.F. Silva et al. 1946 (BHCB); Reserva Biológica de Santa Lúcia, trilha que dá acesso ao túmulo do Augusto Ruschi, 27.X.1999, G.M.F.V. Aquije et al. 279, 280 (BHCB, MBML); Reserva Biológica Augusto Ruschi, Nova Lombardia, 4.X.2001, L. Kollmann \& E. Bausen 4800 (BHCB, MBML); 4.IX.2002, R.R. Vervloet et al. 831 (BHCB, MBML); 21.VIII.2002, G.M.F.V. Aquije et al. 340 (MBML); Trilha da Preguiça, 2.XII.2008, A. Salino et al. 14068 (BHCB); Trilha da Cachoeira, 2.XII.2008, A. Salino et al. 14039 (BHCB).

Material adicional: BRASIL. MINAS GERAIS: Alto Caparaó, Parque Nacional do Caparaó, Vale Verde, 29.XI.2010, F.S. Souza et al. 1158 (BHCB).

Possui distribuição Pantropical (Tryon \& Stolze 1989). No Brasil ocorre praticamente em todos os estados e biomas (Windisch 2014). Epífita, rupícola ou terrícola em depósitos húmicos do solo, no interior de matas de encosta, nebulares ou também em ambientes abertos, sobre rochas úmidas, desde 400-2.000 m alt. 
Espécie de ampla distribuição geográfica e variação morfológica, o qual deixa dúvidas quanto a delimitação exata da espécie. Variações no tamanho e na forma da ala da raque e estípite, associadas ao formato dos indúsios e ao tamanho e inserção dos receptáculos sugerem que existam mais de uma espécie coocorrendo dentro do bioma Mata Atlântica. Algumas morfologias semelhantes as ocorrentes na Mata Atlântica têm sido reportadas como Hymenophyllum decurrens (Jacq.) Sw. e H. trichomanoides Bosch, por Lellinger (1984) para a região Amazônica, porém ainda deve-se estudar com maior detalhe tais variações para o melhor delimitação das espécies. Portanto, neste trabalho optou-se por manter Hymenophyllum polyanthos em um senso genérico, para acomodar tais variações morfológicas.

12. Hymenophyllum pulchellum Schltdl. \& Cham., Linnaea 5: 618. 1830.

Fig. 3d

Rizoma filiforme, pardacento ramificado, 0,3-0,5 mm diam., recoberto por tricomas filiformes, pluricelulares, arruivados, até 1,1-1,2 $\mathrm{mm}$ long., patentes, densos; frondes contíguas, 12,6-33,5 × 2-7 cm; estípite castanho claro a pardacento, cilíndrico, 0,4-0,6 $\mathrm{mm}$ diam., $3,2-6,6 \mathrm{~cm}$ compr., não alado, recoberto na base por tricomas simples iguais aos do rizoma, na porção distal por tricomas estrelados, biestrelados e dendríticos; lâmina linear, pinada-pinatífida, 9,2-27,5 × 2-7 cm, pilosa; raque castanho clara, cilíndrica, não alada, ou alada somente no ápice pela base das pinas decorrentes; pinas lanceoladas a triangulares, pinatífidas, 1,6-4,1 ×0,6-1,2 cm, simétricas, alternas, pecioladas, as apicais adnatas à raque, recobertas por tricomas estrelados, biestrelados ou dendríticos sobre a margem e nervuras, superfície laminar glabra, nervuras sem expansões laminares em ambas as faces; segmentos simples em ambos os lados da pina, os proximais (1-2 pares) por vezes bífidos ou mais decompostos geralmente no lado acroscópico, ca. $0,8 \mathrm{~mm}$ larg., recobertos por tricomas estrelados na margem e sobre as nervuras, ápice arredondado a emarginado, margem inteira, plana; soros em ambos os lados da pina, orbiculares, $0,6 \times 0,8 \mathrm{~mm}$, um por segmento; indúsios orbiculares, imersos no tecido laminar, fendidos até a base, por vezes abertos na maturidade expondo os esporângios, base e ápice arredondados, margem inteira, ciliada com tricomas estrelados; receptáculo filiforme, cilíndrico a capitado, imerso, ca. de $0,4 \mathrm{~mm}$, contendo ca. de 20-30 esporângios.
Material examinado: Castelo, Braço do Sul, 14.VIII.1948, A.C. Brade (ICN). Divino de São Lourenço, Parque Nacional do Caparaó, RPPN Águas do Caparaó, Cachoeira Alta, 12.IX.2011, A. Salino 13853 (BHCB); Parque Nacional do Caparaó, Pedra Escorada, 7.IV.2011, F.S. Souza \& T.M. Machado 1523 (BHCB). Itaguaçu, Morro do Caparaó, 17.VII.2007, P.H. Labiak 4171 (MBML, SP).

Material adicional: BRASIL. MINAS GERAIS: Araponga, Parque Estadual da Serra do Brigadeiro, Serra das Cabeças, no final da trilha a cerca de $100 \mathrm{~m}$ do platô da Serra das Cabeças, 16.IX.2000, G.E. Valente $568 b$ (BHCB).

Ocorre no Neotrópico, desde o México até o sudeste do Brasil (Morton 1947; Stolze 1976), onde ocorre nos seguintes estados: BA, ES, MG, RJ, SP, PR, SC, RS. Epífita ou rupícola em matas ombrófilas montanas e altomontanas, 500-2.000 $\mathrm{m}$ alt.

Espécie confundida com Hymenophyllum rufum, da qual difere pela ausência de tricomas estrelados sobre a superfície laminar. Espécie com interação muito forte com insetos a qual é facilmente observada pela formação de galhas nos rizomas, raque tecido laminar.

13. Hymenophyllum rufum Fée, Crypt. Vasc. Brésil 1: 198, t.70, f.4. 1869.

Fig. $4 \mathrm{a}$

Rizoma filiforme, castanho, ramificado, 0,4-0,5 mm diam., recoberto por tricomas filiformes, pluricelulares, arruivados, até $1,3 \mathrm{~mm}$ long., patentes, densos; frondes contíguas, 10,417,5 × 2,1-4,5 cm; estípite castanho, cilíndrico, 0,4-0,6 mm diam., 3,7-4,1 cm compr., não alado, recoberto na base por tricomas simples iguais aos do rizoma, glabrescente acima, ou com esparsos tricomas estrelados; lâmina ovado-lanceolada, 1-2-pinado-pinatífida, 8,1-14 × 2,1-4,5 cm, pilosa; raque castanho clara, cilíndrica, geralmente alada no último terço distal, pilosa, com tricomas estrelados; pinas triangulares a ovadas, pinadopinatífidas, $1,9-3 \times 1-1,4 \mathrm{~cm}$, simétricas, alternas, pecioladas, as apicais adnatas à raque, levemente ascendentes, recobertas por tricomas estrelados sobre a margem, nervuras e superfície laminar, nervuras sem expansões laminares em ambas as faces; segmentos lineares, bífidos, flabeliformes ou pinados, ca. 1,1 mm larg., recobertos por tricomas estrelados na margem, nervuras e superfície laminar, ápice arredondado ou emarginado, margem inteira, plana; soros em ambos os lados da pina, orbiculares, $0,9 \times 0,9 \mathrm{~mm}$, um por segmento; indúsios orbiculares, imersos no tecido laminar até a metade, fendidos até a base, base aguda, 


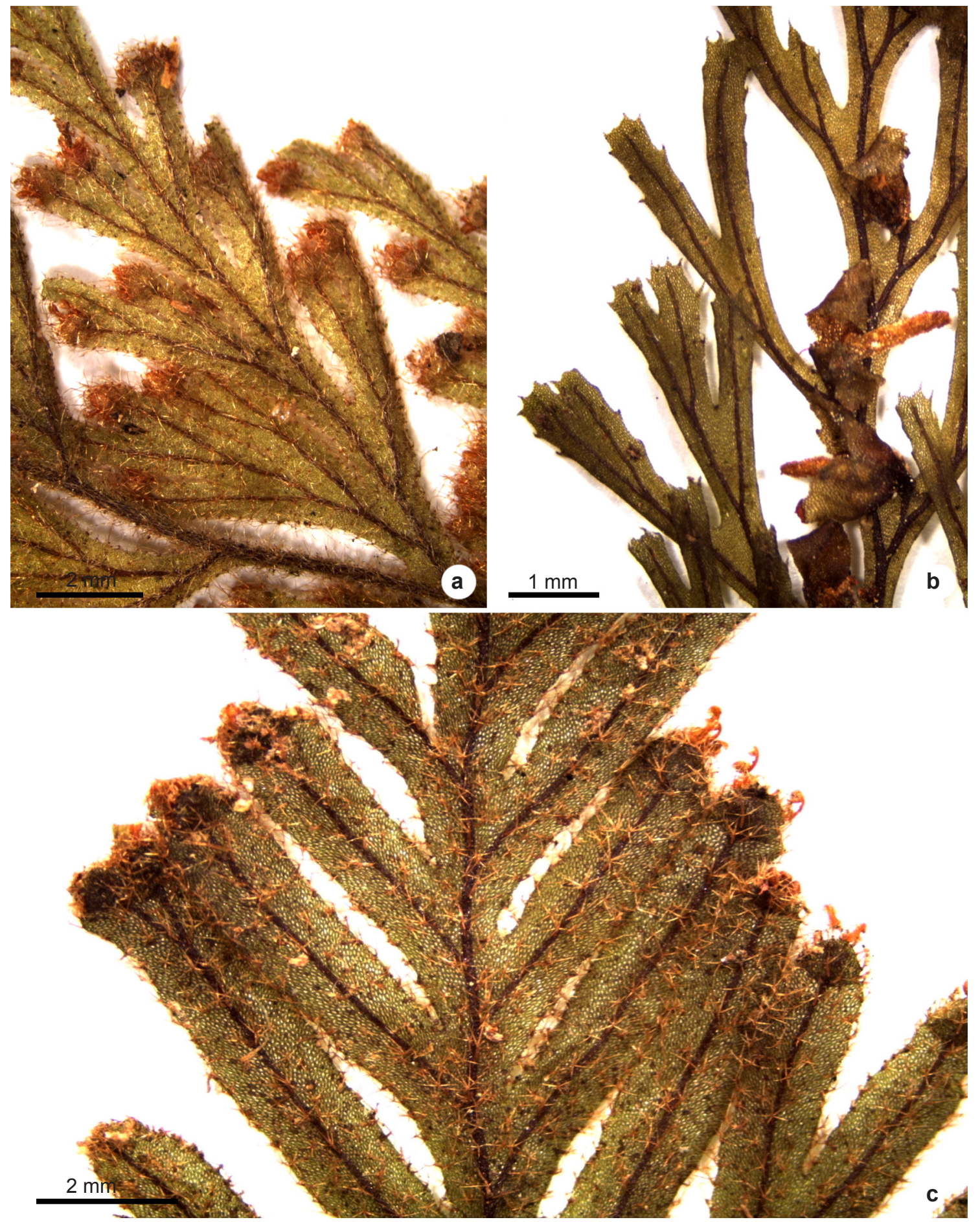

Figura 4 - a. Hymenophyllum rufum - indumento e segmentos férteis. b. H. tunbrigense - margem dos segmentos e indúsio. c. H. venustum - indumento, segmentação e indúsios.

Figura 4 - a. Hymenophyllum rufum - indument and fertile segments. b. H. tunbrigense-segments margin and indusium. c. H. venustum - indumenta, segmentation and indusium shape. 
ápice arredondado, margem inteira, ciliada com tricomas estrelados a biestrelados; receptáculo filiforme, cilíndrico a capitado, imerso, ca. de 0,4 mm, contendo ca. de 20-30 esporângios.

Material examinado: Alto Caparaó, Parque Nacional do Caparaó, Cachoeira da Farofa, 15.X.2010, F.S. Souza et al. 1287 (BHCB).

Material adicional: BRASIL. MINAS GERAIS: Alto Caparaó, Parque Nacional do Caparaó, Vale Verde, 18.XI.2013, T. Almeida et al. 3365 (BHCB).

Espécie endêmica do sul e sudeste do Brasil (Morton 1947), onde ocorre nos seguintes estados: MG, ES, RJ, SP, PR, SC e RS. Epífita ou rupícola em matas montanas e altomontanas, ca. de 800-2.100 $\mathrm{m}$ alt.

14. Hymenophyllum tunbrigense (L.) Sm., Mém. Acad. Roy. Sci. Turin 5: 418. $1793 . \quad$ Fig. 4b

Rizoma filiforme, ramificado, castanho escuro, 0,1-0,2 mm diam., tricomas castanho escuros, simples, 2-5 celulares, até $0,5 \mathrm{~mm}$, mais abundantes nos meristemas; frondes esparsas, 3,1-4,4 × 0,9-1,4 cm; estípite castanho escuro, cilíndrico, 0,1-0,2 mm diam., 0,5-1,6 cm compr., geralmente não alado, ou somente no ápice; lâmina lanceolada, 1-2-pinado-pinatífida, 2,5-3 $\times$ 0,9-1,4 cm; raque castanha, cilíndrica, com esparsos tricomas simples 1-3 celulares, alada, às vezes somente no ápice, margem inteira, plana, ca. $0,1 \mathrm{~mm}$; pinas flabeliformes, pinatífidas ou 1-pinada, até $0,8 \times 0,6 \mathrm{~cm}$, simétricas, alternas, as basais subopostas e pecioladas, as apicais adnatas à raque; segmentos lineares, ca. 0,6 mm larg., 6-10 por pina, margem denteada a serrilhada, ápice denteado, planos; soros restritos ao lado acroscópico da pina, 1-2 por pina, 1,9 ×0,9 mm, encurvados para a face adaxial da fronde; indúsios elípticos, fendidos até a base, ápice arredondado, margem denteada, base cuneada, sustentada por um pequeno pedúnculo; receptáculo cilíndrico a fusiforme, incluso, ca. de 1,2 mm, contendo ca. de 20-30 esporângios desenvolvendo-se ao longo de todo o receptáculo.

Material examinado: Divino de São Lourenço, Parque Nacional do Caparaó, RPPN Águas do Caparaó, Cachoeira Alta, 12.IX.2008, A. Salino et al. 13829 (BHCB).

Material adicional: BRASIL. MINAS GERAIS: Alto Caparaó, Parque Nacional do Caparaó, Vale Verde, 18.XI.2013, T. Almeida et al. 3365 (BHCB). Lima Duarte, Parque Estadual de Ibitipoca, trilha para a Janela do Céu, passando pelo Pico da Lombada e pela Gruta dos Três Arcos, Campo Rupestre, mata de galeria e mata nebular, 22.VI.2007, T. Almeida 1241 (BHCB).
Santo Antônio do Itambé, Parque Estadual do Pico do Itambé, Pico do Itambé, Trilha do Capivari, e grotas perto do pico, campo rupestre e matas nebulares em grotas, 6.X.2006, T. Almeida 549 (BHCB).

Possui distribuição subcosmopolita, conhecida também na Europa, estendendo-se da Noruega até Austrália, Nova Zelândia, Ilhas do Atlântico Sul e Patagônia (Larsen et al. 2013). No Brasil ocorre nos seguintes estados: MG, ES, RJ, PR, SC e RS. Epífita ou rupícola em húmus em mata nebular altomontana, cerca 1.000-2.000 $\mathrm{m}$ alt.

Espécie com delimitação taxonômica ainda discutível e não clara. Windisch (2014) tratou os materiais compatíveis com esta morfologia como Hymenophyllum peltatum (Poir.) Desv., porém, este é um nome mal aplicado ao material ocorrente no Brasil, devido pertencer a um outro grupo de espécies de distribuição mais temperada, e que difere do material aqui ocorrente pela posição dos segmentos nas pinas, que no caso de $H$. peltatum são restritamente acroscópicos (Diem \& Lichtenstein 1959). Os materiais analisados até o momento, tanto do ES como das demais localidades do Brasil e algumas da Europa, deixam dúvidas quanto a aplicação do nome Hymenophyllum tunbrigense para o Brasil. Algumas características como o recorte dos segmentos, tamanho e recorte dos indúsios, bem como a largura e extensão da ala da raque e estípite, diferem das populações Europeias da espécie. Hymenophyllum megachilum C. Presl. também é um nome que tem sido utilizado para tratar os materiais desta morfologia. Porém, ainda deve-se realizar uma avaliação criteriosa do material tipo, e das variações morfológicas para melhor delimitação da espécie e do epíteto correspondente.

15. Hymenophyllum venustum Desv., Mém. Soc. Linn. Paris 6: 332. $1827 . \quad$ Fig. 4c

Rizoma filiforme, ramificado marrom, $0,1-$ 0,2 $\mathrm{mm}$ diam., recoberto por tricomas filiformes, simples, 1-4 celulares, 0,5-1 mm compr., patentes, densos, hialinos a fracamente arruivados; frondes contíguas, pendentes, 3,3-10 × 0,9-1,5 cm; estípite marrom, cilíndrico, 0,1-0,2 mm diam., 0,7-3,5 cm compr., não alado, ou somente no ápice, recoberto por tricomas simples, 1-3 celulares, por tricomas furcados, estrelados ou biestrelados; lâmina lanceolada, 1-pinado-pinatífida, 2,2-9,6 $\times$ 0,9-1,5 cm, pilosa, completamente recoberta (raque, lamina e nervuras) por tricomas estrelados de tamanho uniforme, com célula basal de 0,1 
mm de compr. ou mais; raque castanho clara, cilíndrica, recoberta por tricomas estrelados, alada em toda sua extensão, margem da ala inteira, plana, recoberta na margem e na superfície laminar por tricomas estrelados; pinas lineares, formadas por segmentos simples ou com os basais bífidos, raramente mais decompostos, ascendentes, $5-15 \times 2-5 \mathrm{~mm}$, alternas, primeiro par basal geralmente simples e reduzido; segmentos lineares, até 1,5-2 mm larg., ápice arredondado ou emarginado, margem inteira, recobertos por tricomas na margem e sobre a superfície laminar uniformes, estrelados, com célula basal alongada; soros um por segmento, circulares a ovados; indúsios imersos no tecido laminar até a metade, 1-1,2 × 1-1,2 mm, fendidos até a base, base cuneada, ápice arredondado, margem inteira, recobertos totalmente por tricomas semelhantes aos da lâmina; receptáculo filiforme, cilíndrico a capitado, ca. 0,5 mm compr., imerso, contendo ca. de 15-20 esporângios.

Material examinado: Castelo, Forno Grande, 12.VIII.1948, A.C. Brade 19241 (RB, foto!).

Material adicional: BRASIL. MINAS GERAIS: Olaria, Serra do Cruz, 21.XII.2011, F.E. Alves 179 et al. (CESJ). Ouro Preto, Rio Acima (Nova Lima), 1.I.1937, J. Badini 237 (BHCB). São Gonçalo do Rio Preto, Parque Estadual do Rio Preto, Chapada, mata de galeria atrás da casa velha, na direção do Pico, 21.IV.2007, T. Almeida 797 (BHCB).

Ocorre no sudeste do Brasil, onde ocorre nos seguintes estados: MG, ES, RJ, SP, PR, SC e RS. Epífita em matas úmidas de encosta e nebulares, ca, de 150-2.000 m alt.

Morton (1947) considerou Hymenophyllum venustum como variedade de $H$. fragile $[H$. fragile var. venustum (Desv.) Morton], sem apontar uma justificativa para tal decisão, considerando esta variedade restrita para o sudeste e sul do Brasil (RJ, $\mathrm{SP}$ e SC). Materiais de Hymenophyllum venustum já eram identificados como espécie própria nas coleções de herbário, principalmente pelas identificações de A.C. Brade e A. Sehnem (1971), sob o nome de $H$. raddianum C. Müll. Na América Central, materiais idênticos a Hymenophyllum venustum, em morfologia e ecologia, foram considerados por Morton (1947), Proctor (1985) e Lellinger (1989) como H. lanatum Fée. A análise das descrições, ilustrações e imagem do tipo espécie indica que provavelmente Hymenophyllum lanatum seja um nome sinônimo de $H$. venustum, porém mais detalhamento é necessário para tal afirmação, e, portanto, optou-se por manter $H$. venustum como uma espécie em separado.

\section{Agradecimentos}

Os autores agradecem a todos os curadores das coleções mencionadas, o auxílio no estudo dos materiais; aos coletores que por distintas razões preocuparam-se em coletar estes materiais que podem ser estudados neste momento; e aos revisores que prestaram grande contribuição na melhoria da redação do manuscrito. Também às Instituições Universidade Federal do Rio Grande do Sul e Universidade de Caxias do Sul, a infraestrutura disponibilizada.

\section{Referências}

Andrade RC, Sylvestre LS \& Menezes LFT (2016) Ferns and lycophytes in three fragments of Tabuleiro lowland forest in northern Espírito Santo state, Brazil: composition and floristic relationships in Atlantic forest. Brazilian Journal of Botany 40: 103-113.

Behar L \& Viégas GMF (1992) Pteridophyta da Restinga do Parque Estadual de Setiba, ES. Boletim do Museu de Biologia Prof. Mello Leitão 1: 39-59.

Brade AC (1947) Contribuição para o conhecimento da flora do estado do Espírito Santo (I.Pteridophyta). Rodriguésia 21: 25-56.

Brade AC (1951) Filices novae brasilienses VII. Arquivos do Jardim Botânico do Rio de Janeiro 11: 21-38.

Christenhusz MJM \& Chase MW (2014) Trends and concepts in fern classification. Annals of Botany 113: 571-594.

Diem J \& de Lichtenstein JS (1959) Las himenofiláceas del área Argentino-Chilena del Sud. Darwiniana 11: 611-760.

Ebihara A, Dubuisson J, Itawsuki KI, Hennequin S \& Ito M (2006) A taxonomic revision of Hymenophyllaceae. Blumea 51: 221-280.

Ebihara A, Dubuisson J, Itawsuki KI \& Ito M (2007) Systematics of Trichomanes (Hymenophyllaceae: Pteridophyta), progress and future interests. Fern Gazette 18: 53-58.

Garbin ML, Saiter FZ, Carrijo TT \& Peixoto AL (2017) Breve histórico e classificação da vegetação capixaba. Rodriguésia 68: 1883-1894.

Hennequin S (2003) Phylogenetic relationships within the fern genus Hymenophyllum s.l. (Hymenophyllaceae, Filicopsida): contribution of morphology and cytology. Comptes Rendus Biologies 326: 599-611.

Hennequin S, Ebihara A, Dubuisson J-Y \& Schneider $\mathrm{H}$ (2010) Chromosome number evolution in Hymenophyllum (Hymenophyllaceae), with special reference to the subgenus Hymenophyllum. Molecular Phylogenetic and Evolution 55: 47-59.

Iwatsuki K (1990) Hymenophyllaceae. In: Kubitzki K (ed.) The families and genera of vascular plants. Vol. 1. Pteridophytes and gymnosperms. Springer Verlag, Berlin. Pp. 157-163. 
Kramer KU (1978) The pteridophytes of Suriname: an enumeration with keys of the ferns and ferns-allies. Vol. 93. Natuurwetenschappelijke Studiekring voor Suriname en de Nederlandse Antillen, Utrecht. $198 \mathrm{p}$.

Larsen C, Ponce MM \& Scataglini AM (2013) Hymenophyllum del sur de Argentina y Chile. Gayana Botánica 70: 274-329.

Lellinger DB (1984) Hymenophyllaceae. In: Maguire B. The Botany of the Guayana highlands par XII. Memorial New York Botanical Garden 38: 9-46.

Lellinger DB (1989) The ferns and ferns-allies of Costa Rica, Panamá, and the Chocó: part I, Psilotaceae though Dicksoniaceae. Series: Pteridologia n. 2A. American Fern Society, Washington, D.C. Pp. 185-228.

Lellinger DB (1991) Notes on Neotropical Hymenophyllaceae. American Fern Journal 81: 24-37.

Lellinger DB (2002) A modern multilingual glossary for Taxonomic Pteridology. Pteridologia n. 3. American Fern Society, Washington. 264p.

Morton CV (1947) The American species of Hymenophyllum sect. Sphaerocionium. Contributions from the United States National Herbarium 29: 139-201.

Prado J, Sylvestre LS, Labiak PH, Windisch PG, Salino A, Barros ICL, Hirai RY, Almeida TE, Santiago ACP, Kieling-Rubio MA, Pereira EFN, Øllgaard B, Ramos CGV, Mickel JM, Dittrich VAO, Mynssen CM, Schwartsburd PB, Condack JPC, Pereira JBS \& Matos FB (2015) Diversity of ferns and lycophytes in Brazil. Rodriguésia 66: 1-11.

Proctor GR (1985) Ferns of Jamaica: a guide to the Pteridophytes. British Museum (Natural History), London. 631p.

Pryer KM, Smith AR, Hunt JS \& Dubuisson JY (2001) $r b c L$ data reveal two monophyletic groups of filmy ferns (Filicopsida: Hymenophyllaceae). American Journal of Botany 88: 1118-1130.

Salino A \& Almeida TE (2008) Diversidade e conservação das pteridófitas na Cadeia do Espinhaço, Brasil. Megadiversidade 4: 78-98.

Sehnem A (1971) Himenofiláceas. In: Reitz R (ed.) Flora Ilustrada Catarinense (Himen). Herbário Barbosa Rodrigues, Itajaí. 98p.

Smith AR, Pryer KM, Schuettpelz E, Korall P, Schneider H \& Wolf PG (2006) A classification for extant ferns. Taxon 55: 705-731.

Stolze RG (1976) Ferns and ferns allies of Guatemala: part I, Ophioglossaceae through Cyatheaceae. Vol. 39. Field Museum of Natural History, Chicago. Pp. 1-90.

Sylvestre LS, Almeida TE, Mynssen CM \& Salino A (2016) Samambaias e Licófitas da Reserva Natural Vale, Linhares, ES. In: Rolim SG, Menezes LFT \& Srbek-Araujo AC (eds.) Floresta Atlântica de Tabuleiro: diversidade e endemismos na Reserva Natural Vale. Rona ed., Belo Horizonte. Pp. 157-166.

Thiers B [continuamente atualizado]. Index Herbariorum: a global directory of public herbaria and associated staff. New York Botanical Garden's Virtual Herbarium. Disponível em $<$ http://sweetgum.nybg. org/science/ih/>. Acesso em abril 2014.

Tryon RM \& Stolze RG (1989) Pteridophyta of Peru, Part I. Fieldiana Botany 20: 1-145.

Viégas-Aquije GMF \& Santos IKF (2007) Levantamento Florístico de Pteridófitas da Reserva Biológica Augusto Ruschi, Santa Teresa, ES. Revista Brasileira de Biociências 5: 909-911.

Windisch PG (1992) Trichomanes crispum L. (Pteridophyta, Hymenophyllaceae) and allied species. Bradea VI: 78-117.

Windisch PG (2014) Hymenophyllaceae (Polypodiopsida) no estado do Rio Grande do Sul. Instituto Anchietano de Pesquisas, Herbário PACA, Unisinos, RS. Pesquisas, botânica 65: 15-48. 
